\title{
Between separation and celebration: Perspectives on the ethical-political preaching of Desmond Tutu ${ }^{1}$
}

\author{
Cilliers, Johan \\ Stellenbosch University \\ jcilliers@sun.ac.za
}

\begin{abstract}
Recognising the complexity of a pluralistic South African society, this article attempts to identify four ethical movements in preaching in the past, as well as the present. These movements are from silence to struggle, from separation to celebration, from lamenting to longing, and from shaming to playing. In this regard, cognisance is taken in particular of the sermons, speeches, and letters of Archbishop Desmond Tutu. The paper concludes with a discussion of a classic South African film from 1976, entitled e'Lollipop.
\end{abstract}

Keywords

Separation, Celebration, Lamenting, Longing, Shaming, Playing, Ethical-political preaching

\section{A very strange society}

After an American journalist, Allen Drury, visited South Africa in the late 1960's, he felt the need to write a book entitled: A Very Strange Society. ${ }^{2}$ South Africa was then, and indeed still is today, a very strange society, with many layers of complexities and paradoxes. If Drury could have visited South Africa last year, say during the $5^{\text {th }}$ national democratic elections,

1 Abbreviated version of a paper delivered at the Internationalen BugenhagenSymposium. Atelier Sprache Braunschweig / Theologische Fakultät Leipzig, on the theme "Ethisch predigen - kann man das, soll man das?". 25-27 September 2014.

2 Allen Drury, A Very Strange Society. A journey to the Heart of South Africa (New York: Trident Press, 1967). 
held on the $7^{\text {th }}$ of May 2014, he probably would have written a follow-up: Still a Very Strange Society. We are the "Rainbow Nation", but, at the same time, in the words of Archbishop Desmond Tutu: "Who in their right mind could have believed South Africa could be an example of anything but the most awful ghastliness? We are such an unlikely lot."3

This complex nature of South African society poses several challenges to anyone who dares to speak about political-ethical preaching. The pluralistic fabric of our South African society makes it difficult to describe, amongst other things, the notion of "ethical preaching", or "ethics" for that matter. What is "right" for one (or one group), may be "wrong" for another; and what is "wrong" for one, may be "right" for another. When South Africans speak about "change" or "transformation", they are not necessarily on the same page. The best we can hope for in our pluralistic society is a type of bricolage among different dialogue partners who speak out of, but hopefully also beyond their own traditions. ${ }^{4}$

In this article, I limit myself to brief comments on some sermons, speeches, and letters by Archbishop Desmond Tutu - that "tiny pastor with a huge laugh from South Africa who became our global guardian." I do this because Tutu has become known, inter alia, for his ability to do exactly this: speaking from his Christian convictions in such a manner that it is applicable beyond his convictions. ${ }^{6}$

In order to understand his approach to ethics, one should keep Tutu's basic Ubuntu paradigm in mind. The concept of Ubuntu, although somewhat elusive, has become well known all over the world as being typical of African and specifically South African culture. Although Ubuntu as African cultural expression could strictly speaking not be called "theology," there are many prominent theologians who interpret this concept in theological terms. Desmond Tutu, for instance, has developed and practiced what could

3 BBC News, January 2000.

4 In this regard, bricolage refers to the borrowing among partners of what is handy, appropriate and communicative in jostling, negotiating and persuading towards a common moral sense. Cf. LS Cahill, From Christ to the World. Introductory Readings in Christian Ethics (Grand Rapids: Eerdmans, 1994), 373.

5 Time Magazine, 11 October, 2010.

6 One of the famous sayings of Tutu is: I am such a good ecumenical because I am such a good Anglican! 
be called a "theology of Ubuntu"? Tutu's theology is probably one of the most representative expressions of African Ubuntu. For Tutu, Ubuntu has a profound theological meaning, because God has created us to need each other. We are made to be part of a "delicate network of interdependence." In this ethical paradigm, being there for one another is of paramount importance. One could indeed say that Tutu has been a proponent of a sacrificial ethics, rather than an achievement ethics. ${ }^{9}$

So, let me be brave, and following the cues left by Desmond Tutu, offer four brief perspectives on "ethical preaching", taken from our past, and our present. These four perspectives, or rather movements, are intertwined, and I venture them, knowing well that there are many more to be explored.

\subsection{Between silence and struggle}

The first perspective - or observation - is simply that a large part of the church was silent during the time of apartheid. Silence is a distinct form of (un)ethical preaching. It either expresses fear for the status quo, or acceptance thereof. It stabilizes and legitimizes the powers that be. It presupposes a certain ethical stance, which says: the status quo is good, or at least bearable. This syndrome of silence is not new, at least within certain sectors of the South African context. Research done on trends in Afrikaans religious programmes as far back as 1987 indicates that the religion that was offered to ordinary Afrikaans-speaking people then was almost always imperative in nature, but not as an appeal that affects the daily and concrete reality. It rather was a type of alien-to-daily-life, non-existential appeal on the grounds of pietistic potential. The programmes' contents said virtually nothing about the issues that, for instance, received attention in the daily press. This research, conducted in conjunction with the department of journalism at the Stellenbosch University found that not one of the ten most commented on issues of the day was reflected in the sermons that were broadcast. ${ }^{10}$ Socio-political issues like the following, received no, or

7 Michael Battle, Reconciliation: The Ubuntu Theology of Desmond Tutu (Cleveland: Pilgrim, 1997), 5.

8 Battle, Reconciliation, 35.

9 Allen, Rabble-Rouser for Peace, 347.

10 Cf. BA Müller, Tendense in Afrikaanse Godsdiens Programme (Stellenbosch: University of Stellenbosch, 1987), 44-46. Allan Boesak, a well-known South African preacher 
very little attention in a total of 165 sermons and meditations preached on television and radio between April and November 1987: ${ }^{11}$

- Violence, including murder and crime: 0,06\%

- Human Rights: 0,03\%

- Detention and political trials: $0 \%$

- Freedom of press: 0\%

- Military violence, Governmental acts: 0\%

- The Right to protest, protest actions: $0 \%$

- Group Areas Act 0\%

- Discrimination, e.g. in education, health services, wages, etc: $0 \%$

- Poverty, hunger, housing: $1,38 \%$

- Joblessness: 0,03\%

- Sexuality: $1 \%$

- Drugs, alcoholism: 0,06\%

- Ecological issues: 0\%

This is truly remarkable; even more so, sad. ${ }^{12}$ Nothing to be said over the Group Areas Act in 1987, and the forceful removal of millions of people? Not a single word about discrimination? Not one sermon on poverty and hunger?

Of course not all were silent during the time of apartheid. Besides the syndrome of silence, South Africa also produced its share of outspoken preachers like Desmond Tutu and others - confronting, and struggling

articulates his aversion of pietistic traditions and preaching in the church in no unclear terms, stating that "this kind of theology is often the handmaid of authoritarian structures that preserve the status quo within the church, with the result that the church is being held back to an era that has irrevocable passed." For Boesak, the gospel - and preaching - is about this world, not an "other-worldly theology". Allan Boesak, The Finger of God, Sermons on Faith and Responsibility. Translated from Afrikaans by Peter Randall (Johannesburg: Raven, 1979), 4-5.

11 Müller, Tendense, 10, 29.

12 Allan Boesak's words ring true: “...the silence that some want the church to maintain on these issues means that they are affirming the status quo." Boesak, The Finger of God, 11. 
with, the status quo. They represent a distinct, South African flavour of ethical preaching. ${ }^{13}$

In a remarkable letter, which remained unpublicised for more than three decades, Tutu addressed the then Prime Minister, PW Botha, and confronted him about the forced separation of white and black people in South Africa in no uncertain terms - specifically in terms of the forceful removal of between two and three million black people from their homes. ${ }^{14}$ This letter was written on 5 July 1979 - a time of socio-political turmoil in South Africa as seldom experienced before. ${ }^{15}$ The tension of this catastrophic phase of South African history forms the contextual background of the letter - a profound ethical "sermon" in its own right.

13 One thinks also of the preaching of Allan Boesak and Beyers Naudé. Cf. Len D Hansen (Hrsg.), The legacy of Beyers Naude (Beyers Naude Centre Series on Public Theology, Vol. 1), Stellenbosch 2005; ders./Robert Vosloo (Hrsg.), Oom Bey for the future: Engaging the witness of Beyers Naude (Beyers Naude Centre Series on Public Theology, Vol. 2), Stellenbosch 2006; Johan Cilliers, The Living Voice of the Gospel? Re-hearing a Prophetic Voice from Apartheid South Africa, in: Jan Hermelink \& Alexander Deeg (Hrsg.), Viva Vox Evangelii - Reforming Preaching. Societas Homiletica 9 (Leipzig: Evangelische Verlagsanstalt, 2013), 161-180.

14 Desmond Tutu, God is not a Christian. Speaking Truth in times of Crisis (London: Rider, 2011), 142-147.

15 The details of this period need not be repeated here; suffice to say that the country was balanced on a knife-edge, with a full scale civil war and unimaginable bloodshed a real possibility. For an extensive discussion, cf. CFJ Müller (ed), Vyfhonderd jaar Suid-Afrikaanse geskiedenis (Kaapstad: Tafelberg, 1980), 510-520. The period 1960 to 1980 was, on the one hand, characterized by post-war prosperity among a large part of the white population, and, on the other hand, by a growing relational problem and alienation among the various population groups. In this respect, the events at Sharpeville (1960) formed a type of watershed, and focused the world's attention on South Africa, with increasing foreign isolation, sanctions, and internal unrest and violence. South Africa's subsequent withdrawal from the Commonwealth (May 1961) caused its greatest economic crisis since the depression of 1930 to 1932 . A combination of political, economic and social factors escalated into another watershed moment for South Africa, with the youth taking to the streets in the Soweto-uprising of 1976, resulting in a governmental clamp-down, called the "state of emergency". All of this eventually led to the release of Nelson Mandela, resulting in the first democratic general elections on 27 April 1994, which were described by many as "nothing short of a miracle". Time and space constraints do not allow me to describe the momentous events leading up to this breakthrough in detail. For an overview of this period, cf. Hermann Gilliomee/Bernard Mbenga (eds), New History of South Africa (Kaapstad: Tafelberg, 2007), 330ff. Cf. also Johan Cilliers, The Living Voice of the Gospel?, 161-181. 
In a moving fashion, Tutu appeals not only to PW Botha's Christian belief ("as one Christian to his fellow Christian", ${ }^{16}$ ) but he makes liberal use of passages of Scripture, and he ends the letter by stating that he will continually pray for PW Botha and his colleagues, "that you may be instruments of his divine gracious will in this beautiful land which we all love so deeply." ${ }^{17}$ It is exactly within this profound theological framework that Tutu speaks some of his sharpest words of confrontation, of struggling with the system of apartheid:

I write to you to say that the policy of population removal and resettlement is quite indefensible on moral and pragmatic grounds... But it is the moral aspect that has shattered me and that I believe you and your colleagues must be unaware of. And it is that human persons are treated as if they are less than that. I must be careful not to use emotive language, but Mr Prime Minister, I cannot avoid speaking about the dumping of people as if they were things, with little prior consultation about how they felt about things and almost certainly scant attention being paid to how they feel... I am trying to be as restrained as possible because I want to confess to you that at this moment as I write I am deeply agitated and angered by what I have seen... We want justice, peace, and reconciliation in our land, and these will come as we strive to remove all which makes people less than what God intends them to be. We will be free together or not at all." 18

There seems to be almost something Pauline about this ethical approach and struggle of Tutu: he appeals for change on the grounds of the reality of an identity, in this case - the outspoken Christian belief of PW Botha, and that of the whole apartheid government, for that matter. ${ }^{19} \mathrm{He}$ is agitated and angered, because PW Botha and his government are not acting according

16 Tutu, God is not a Christian, 142.

17 Tutu, God is not a Christian, 147.

18 Tutu, God is not a Christian, 143-146.

19 Apartheid was openly sanctioned by certain Christian Churches such as the Dutch Reformed Church, and many of the members of Parliament were leaders (elders and deacons, even former preachers) in these churches. For Paul's view on ethics cf. for instance G Walter Hansen, Galatians (Illinois: Inter-Varsity Press, 1994), 25ff. 
to the ethical parameters of their so-called Christian confession. This basis of appeal adds theological gravitas to Tutu's analysis of the situation, making it difficult for those who are addressed to ignore it. ${ }^{20}$

Fifteen years after Desmond Tutu wrote his letter to PW Botha, on 27 April 1994, the first democratic general elections took place, which were described by many as "nothing short of a miracle." South Africa's young democracy, the "Rainbow Nation", recently celebrated its twentieth birthday. There is much to be applauded about the current state of affairs in our country, but also much to be lamented. Many people feel that we need ethical preaching again, but that the prophets have gone, that (un)ethical silence has once again fallen upon us. ${ }^{21}$

Embedded in Article 15 of the Bill of Rights of the South African Constitution (drafted in 1996), are the three principles of freedom of religion, belief and opinion. These principles give recognition to the reality of religious diversity in South Africa, the separation between religion and state and equal opportunities for all religions in societal life. ${ }^{22}$ Although this might seem like a utopian state of affairs, the effect could in fact be a new syndrome of silence in South Africa - no longer feeling the need to speak out against certain ethical issues in society. This temptation does not only apply to churches who supported the former liberation movements whose members are now in government, but also to those churches who supported the apartheid system and who intends to restore their credibility in the South African society. The former opponents of apartheid run the risk of showing uncritical loyalty to the current government, while the former defenders of apartheid might easily succumb to the temptation of political

20 In this instance, Tutu argues on the basis of his and PW Botha's Christian beliefs. Many of his ethical stances are however also applicable to other religions and non-Christians. He keeps on insisting that "God is not a Christian", and that there is a moral core to the universe - of importance for people of all races, but also beliefs. Cf. Tutu, God is not a Christian, 3ff; $206 \mathrm{ff}$.

21 Cf. my discussion in Johan Cilliers, Predigt als politisches und eschatologisches Ereignis. Wahrnehmungen aus Sudafrika. In Erlebnis Predigt. Eine Veröffentlichung des Ateliers Sprache e.V, Braunschweig. Herausgegeben von Alexander Deeg (Leipzig: Evangelische Verlagsanstalt, 2014), 125-142.

22 Gerrie Lubbe, A Christian perspective on religious freedom in the South African context. In J Kilian (Ed), Religious Freedom in South Africa (Pretoria: UNISA, 1993), 146. 
correctness, and a consequent uncritical stance towards the government, in view of regaining public credibility. ${ }^{23}$

This, in my opinion, is in fact what is currently happening in South Africa. Between uncritical loyalty and political correctness, the ethical voice of the church has, to a large extent, been silenced, and in effect, neutralised.

\subsection{Between separation and celebration}

The current silence of at least a part of the church in South Africa could indeed be attributed to a hesitancy to speak out about social issues. These churches have burnt their fingers, and want to be political correct. To a degree this is understandable, taking into account the type of sermons that were preached during the time of apartheid, in an effort to anchor the ideology of "us" against "them". ${ }^{24}$ In my opinion, this anchoring of apartheid also represents a (perverted) type of ethical preaching, i.e. an effort to structure society according to certain ideals.

The threefold homiletical structure of these so-called ethical sermons could be summarised as follows: the presupposition of an analogy between biblical characters and/or events and the Afrikaner "volk"; the moralising of imperatives, in order to inspire religious activism; and the demonising of the "enemy". ${ }^{25}$ All of these movements can be seen in the following example, taken from a sermon on Est 4:14. I quote this as a good example of a bad example of a sermonic expression of the ethics of apartheid - that created seemingly impassable rifts between "us" and "them" in a rhetorically powerful manner:

Those who can discern the signs of the times correctly will agree:

we, the Afrikaner nation and Christendom in Southern Africa expe-

23 Cf. Nico Koopman, Freedom of religion and the prophetic role of the church. In NGTT 43/1,2 2002, 237-247.

24 These sermons strove to legitimise apartheid within a specific understanding of theology, inter alia through the usage of a select repertoire of God-images. A reduced number of God's "characteristics" were presented, for example that God "determines the destinies of nations," or that God is the "Almighty," etcetera. Other characteristics, such as God's righteousness and especially God's vulnerability were avoided because it was problematic to fit them into the basic motif of inspiring and stabilising patriotic moralism. Cf. Johan Cilliers, God for us? An analysis and assessment of Dutch Reformed preaching during the Apartheid years (Stellenbosch: Sun Press, 2006), 77-78.

25 Cf. Johan Cilliers, Predigt als politisches und eschatologisches Ereignis, 133. 
rience times of crisis as never before. About this, experts of our time agree ... Our greatest danger is not the Communist force of arms or the military power of some or other country; our greatest threat is not a struggle against flesh and blood, but against the subtle power of the dark, that is unobtrusively and slowly but surely breaking down our nation and our Christian believers' spiritual standards, our sense of moral and spiritual values. Modern Hamans threaten our future existence. All around us we again hear the cry of the French Revolution: equality, liberation and brotherhood and a misplaced emphasis is placed on unity - often to the detriment of the natural differences between races, nations and churches, as willed by God; and a false ecumenicity is striven towards, to the detriment of pluriformity or variety. All over, we also observe the signs of a so-called dialogue between Protestantism and Roman Catholicism the truth and the lie. The slogan of the day is: away with differences - one church, one world, and one nation! And behind this slogan we see the Sovereign of the Dark, who is preparing the world's scene for the appearance of the Antichrist. May God open our eyes before it is forever too late. We are in a crisis! ${ }^{26}$

It seems to be a startling fact that the mentality of "us" against "them", so vehemently preached in sermons like these, is once again rife in South Africa. Or, perhaps it has never left us? In a recent survey, conducted in Gauteng, the economical heartland of South Africa, it was found that the level of trust between black people and white people in South Africa is diminishing year after year. ${ }^{27}$ The number of black people saying they would never trust white people increased from 68\% in 2009 to $73 \%$ in 2013. Over the same period, the perception by white people had increased from $40 \%$ in 2009 to $44 \%$ in 2013. The survey also indicated that this notion of mistrust was held deeply in the "older" townships. ${ }^{28}$ The study found that in those

26 As quoted from Johan Cilliers, God for us?, 67.

27 The GCRO, a partnership between the University of Johannesburg, the University of the Witwatersrand, the Gauteng government, and the SA Local Government Association, conducted a study with over 25000 people to gauge satisfaction levels with governance in Gauteng province. At least 60 respondents per ward were sampled in each metropolitan municipality and 30 per ward in local municipalities.

28 Those townships included Mamelodi, Soshanguve, Mabopane in Tshwane, Alexandra, Soweto in Johannesburg, Khutsong in the West Rand, Thokoza, Tsakane and Tembisa 
townships, $77 \%$ to $100 \%$ of the respondents believed that black people and white people would never trust each other. According to the Director of the Survey, Professor David Everatt: "Racial attitudes are a mess in the country." ${ }^{29}$

It is as if the ethics of separation between "us" and "them", so integral to the ideology of apartheid, has come back to haunt us.

But, now as in the past, swimming against this stream, Tutu calls upon South Africans not to separate, but rather celebrate their diversity. This is a theme that has dominated the ethical thought of Tutu from the beginning. In a speech to the United Nations' Commission on Human Rights in Geneva in 2001, Tutu states:

We belong in a world whose very structure, whose essence, is diversity, almost bewildering in extent. It is to live in a fool's paradise to ignore this basic fact... We live in a universe marked by diversity as the law of its being and our being. We are made to exist in a life that should be marked by cooperation, interdependence, sharing, caring, compassion, and complementarity. We should celebrate our diversity; we should exult in our differences as making not for separation and alienation but for their glorious opposites. The law of our being is to live in solidarity, friendship, helpfulness, unselfishness, interdependence, and complementarity, as sisters and brothers in one family, the human family, and God's family. Anything else, as we have experienced, is disaster...Our survival as a species will depend not on unbridled power lacking moral direction, or on eliminating those who are different and seeking only those who think and speak and behave and look like ourselves... There is room for everyone; there is room for every culture, race, language, and point of view. ${ }^{30}$

Could one find a starker contrast than between the apartheid sermon quoted above, and this utterance of Tutu? The one separates; the other celebrates.

on the East Rand, along with Sebokeng in the Vaal.

29 Other surveys seem to confirm these sentiments. Cf. for instance The South African Reconciliation Barometer Survey: 2011 Report. Ed. Kate Lefko-Everett, Ayanda Nyoka and Lucia Tiscornia. Published by the Institute for Justice and Reconciliation.

30 Tutu, God is not a Christian, 50-52. 
The one fights against the exposure to the so-called "enemy"; the other stands in awe of our diversity. The one divides; the other is amazed. It is on these grounds - the inter-dependence of human beings, as envisioned by his Ubuntu-theology - that Tutu bases his ethical appeals. This represents an ethics not of fear for the enemy, but rather acceptance, but even stronger than that, an ethics of celebration of the so-called "other". Fear does not transform anybody, at least not fundamentally, and not in the long run; awe and celebration invites one into a world that is not threatening. This mode of ethics is no whip, chasing people into an enclosure; it rather is a hand, beckoning. It indicates a world, an alternative, of which one could voluntarily say: this is where I want to be; in this space I long to live.

\subsection{Between lamenting and longing}

According to many commentators, the South African "rainbow nation" is losing its kaleidoscopic charm. Many are lamenting the demise of many aspects of the era that was so boldly inaugurated by Nelson Mandela and others. Some of these sighs express a longing for the "good old days" of apartheid, but others, like Desmond Tutu, are lamenting what has gone wrong, without giving up the hope of an alternative future. In a speech, delivered in 2006, and entitled "What has happened to you, South Africa?" Tutu states his sadness concerning certain events in our country. ${ }^{31} \mathrm{He}$ laments and sighs - in protest:

31 In this speech, Tutu openly spoke about his dismay that someone like Jacob Zuma could be elected as President of South Africa. Although retired, Tutu still exposes injustices in society, whatever form it takes on. He once stated: "I do not do it because I like to do it... I cannot help it when I see injustice. I cannot keep quiet...” Desmond Mpilo Tutu, Hope and Suffering. Sermons and Speeches (Johannesburg: Skotaville Publishers, 1983), xiii. In recent times he has spoken out against the massacre of mine workers by police at Marikana, the waste of almost 250 million Rand in so-called "security upgrades" being done at president Jacob Zuma's private residence at Nkandla, and in particular the plight of abused woman and children, and the fragmentation of family life in South African society. In a recent appearance on national television, he even said: "Be aware. We will start praying for the downfall of the ANC...." The paradoxes of the past, and the paradoxes of the present, still plaguing our country, perplex Tutu. He protested against the "God-with-us" theology of the apartheid era, and he protests against the "God-with-us" theology of the current ANC Government, from whom we often hear statements like: "God was there at the inception of the ANC - therefore it is the only Party to vote for"; "If you vote for any other Party than the ANC, you will go to hell (sic)"; "If you vote for the ANC, it is your ticket to heaven"; "The ANC will rule until Jesus comes again..."; and so on. 
My naiveté was that I believed that these noble attitudes and exalted ideals (of the liberation struggle, JC) would, come liberation, be automatically transferred to hold sway in the new dispensation. We South Africans were a special breed, and I believed we would show the world, hag-ridden especially in Africa by the scourge of corruption, that we were a cut above the hoi polloi. Wow! What a comprehensive letdown - no sooner had we begun to walk the corridors of power than we seemed to make up for lost time... The trouble with these people in government is that they've got power now and they believe that they're going to have power forever, and you have to keep warning them. The Afrikaner Nationalists thought they were invincible. Let me tell this ANC government what I told the Afrikaner Nationalist government: You may have power now, but you're not God. Remember: you're not God, and one day, you'll get your comeuppance. ${ }^{32}$

Desmond Tutu often uses the exclamation "Wow!" mostly to express his amazement at something good. Here he uses it as an expression of disbelief: how can this be? It signifies the tension between sighing and yearning for a better future. As a matter of fact, longing for a better South Africa, yearning for the alternative, has always been part and parcel of Tutu's ethical thinking. Speaking to a white audience in 1978, he declares:

Come, let us walk tall together into the wonderful future that can be ours, black and white together, a wonderful future for our children, black and white together. ${ }^{33}$

This phrase: black and white together, in fact could be called a key rhetorical technique used by Tutu in numerous sermons and speeches. It describes the content of the future he was, and to a large extent still is, longing for. If it is indeed the task of the church "to show the world where her future lies", as Geoffrey Wainwright insists, this is what Tutu keeps on doing. ${ }^{34}$

32 Tutu, God is not a Christian, 202, 212.

33 Tutu, God is not a Christian, 133.

34 Geoffrey Wainwright, For Our Salvation. Two Approaches to the work of Christ (Grand Rapids: Eerdmans, 1996), 121ff. 


\subsection{Between shaming and playing}

Not everybody agrees with the ways in which Tutu has been articulating his ethical views - not during the time of apartheid, and surely not now. Tutu was once called "Public Enemy Number One", and blatantly accused of being "on a wicked path". ${ }^{35}$ In some political cartoons of the day, Tutu was betrayed as a devilish figure, complete with trident, tail, and horns, or as a vulture sitting in a tree. ${ }^{36}$ Tutu is also not popular with the ANC government of today, often openly criticising people like President Jacob Zuma, and former Finance Minister Trevor Manuel, to name but a few. ${ }^{37}$ He has been stereotyped and shamed by the Apartheid government of the past, and he is being stereotyped and shamed by the ANC government of the present.

The remarkable thing is that he mostly reacts in a mischievous way, using rhetorical techniques like irony, indirect speech, parody, and lampooning to state his convictions and envisage alternatives, much like the so-called fools of all ages and cultures. ${ }^{38} \mathrm{He}$ could indeed be called a "rabble-rouser", as his authorised biography states. ${ }^{39} \mathrm{He}$ often relativizes serious situations by means of humour, acting as a type of clown or court jester or joker. In the process, he does not take himself too seriously. ${ }^{40}$

In my opinion, this behaviour of Tutu signifies a remarkable ethics of playfulness. Tutu yearns for the future, but he does this not only through expressions of indignation and anger, but also in a playful manner. $\mathrm{He}$ laughs as much as he weeps - for a better future. ${ }^{41}$

It is no wonder that Tutu often links the future to children. "When we see the face of a child", he says, "we think of the future. We think of their

35 According to Prime Minster PW Botha. Allen, Rabble-Rouse for Peace, 6.

36 For instance by cartoonist TO Honnibal during the eighties.

37 Tutu, God is not a Christian, 203, 211.

38 Cf. Charles Campbell and Johan Cilliers, Preaching Fools. The Gospel as a Rhetoric of Folly (Baylor University Press: Waco, Texas), 181ff.

39 John Allen, Rabble-Rouser for Peace. The authorised biography of Desmond Tutu (London: The Free Press, 2006).

40 Cf. Allen, Rabble-Rouser for Peace, 238.

41 Cf. Hennie Pieterse, "Hoe kom God aan die woord in die prediking? 'n Vaste vertroue op God is teologies noodsaaklik," Practical Theology in South Africa 20, no. 2 (2005): 122. 
dreams about what they might become, and what they might accomplish." ${ }^{\prime 2}$ For him, the future is tomorrow's child - to borrow a phrase from Rubem Alves. For him, as for Alves, to hope is to hear the melody of this future. Faith is to dance it. ${ }^{43}$

In a playful manner, children imagine and anticipate an alternative world. To be a child is to play. Through their play, children call for new paradigms, and surprising re-configurations - without them knowing it. Through their play, they breathe new life into archaic forms; lifting and shifting that, which seems immobilized and immoveable. Or, again in Tutu's words: "Children are a wonderful gift. They have an extraordinary capacity to see into the heart of things and to expose sham and humbug for what they are." ${ }^{44}$

Play imaginatively creates its own times and spaces and rhythms, in which the normal order of things is no longer applicable. Dare I say this ethically? The playful exuberance of children reminds us of the dawning of the new age in the midst of the old, and calls upon us to act accordingly. Again, this type of ethics is no whip or threat, but invitation to step out of the sham and humbug of old patterns, into the imaginative space of new possibilities.

Play is not about production, not about an ethics of achievement, but about joy. To be able to play, one needs imagination. Imaginative play implies a radical critique of a society that opts only for productivity and success, often sacrificing the joy of imagination. Play stretches the imagination, opening up possibilities unsought and unthought-of. It asks, "What if...?"

42 www.huffingtonpost.com/...tutu/facing-the-future-global_b_544449.htm...

43 Rubem Alves, Tomorrow's Child. Imagination, Creativity, and the Rebirth of Culture (London: SCM Press, 1972), 195.

44 thinkexist.com/.../children-are-a-wonderful-gift-they-have-an/360729.ht...

Indeed, through their play children remind us of the basics of life. We have been created to play, as the Dutch cultural philosopher Johan Huisinga had already pointed out in his classic 1938 work entitled Homo ludens (playful human beings). Not only are we homo sapiens (intelligent beings), or homo faber (beings utilizing tools), or homo erectus (beings standing upright), we are also homo ludens -playing and playful creatures. According to Huizinga, play lies at the root of all culture, but it cannot be simply equated to life. It is something radically different. As a matter of fact, it interrupts the daily routine of life and frees us from the ordinary. 
Children somehow sense that the gift of tomorrow is a gift of grace to be celebrated today. As a matter of fact, another word for play is grace. Playing children are keepers and guardians of grace. They sense another world.

But perhaps this imaginative anticipation of an alternative society, this ethics of longing for, and seeing the future through the face of a playing child is best said aesthetically, as is often the case. An example of this comes, strangely enough, in the form of a classic film, produced in South Africa already in 1976 - completely against the grain of the apartheid ethics of the time. The film was entitled e'Lollipop, sometimes also advertised as Forever Young, Forever Free, and is basically about the friendship between a black boy and a white boy, in a time when black and white were not supposed to mix.

The two children - Tsepo (Muntu Ndebele) and his orphaned friend Jannie (Norman Knox) meet when Jannie's parents die tragically in a car crash in the Lesotho Mountains. Jannie is sent to a missionary station in Tsepo's village where they become best friends. Together with their dog Sugarball, life is full of childhood fun and antics until tragedy strikes again: Jannie, aged 13, is seriously injured when one of their games goes horribly wrong. Tsepo and his community pull together so that Jannie can receive emergency medical treatment.

e'Lollipop is a true South African classic of international stature that transcended the apartheid boundaries of its day. Despite the fear, hatred and brutality that plagued South Africa in the mid-1970's, e'Lollipop told a story of friendship and commitment that confronted apartheid South Africa with images of two children, black and white, playing together. Pictures like the following spoke more than a thousand ethical sermons. It angered those in power to such an extent, that the film barely escaped being banned. In my imagination, I can hear Desmond Tutu not only chuckling, but laughing out loud - wishing he could be part of the play. 


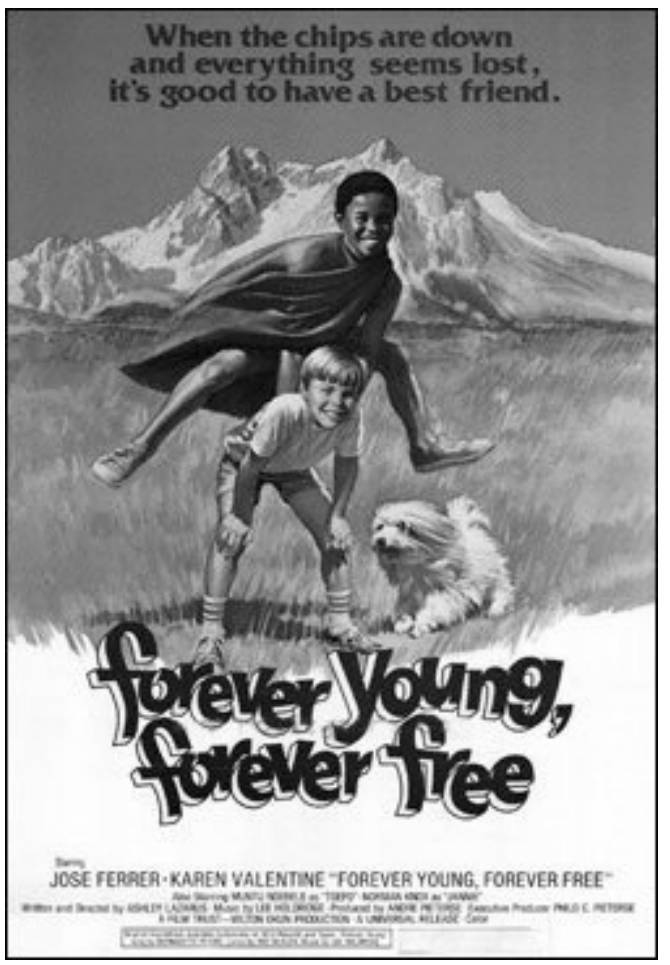

Somehow, the film acted as a type of imaginative alternative, indeed a proleptic fulfilment of Desmond Tutu's longing for a South Africa in which black and white together, could play as children. For many South Africans living in the seventies, this would have been unthinkable, indeed the strangest of all societies...

It still is.

Wow! 